\title{
The Brazilian Workers' Party
}

\section{Recent Histories/Recent History}

\author{
Stanley A. Gacek
}

Emir Sader, Ken Silverstein, Without Fear of Being Happy: Lula, The Workers' Party and Brazil (New York/London: Verso 1991).

Margaret E. Keck, The Workers' Party and Democratization in Brazil (New Haven: Yale University Press 1992).

Jorge G. Castaneda, Utopia Unarmed: The Latin American Left After the Cold War (New York: Alfred A. Knopf, Inc. 1993).

Charles DeGaulle once made the caustic quip that Brazil "is not a serious country." Unfortunately, this misguided and tragically ignorant remark evinces a prejudice which has not been the exclusive monopoly of the right. Throughout the 198s, much of the North American left virtually ignored a remarkable mass movement for democratic change in Latin America's largest country, focusing almost exclusively on the heroic popular struggles in Central America and Southern Africa. This is most ironic, since the Brazilian Workers' Party (Partido dos Trabalhadores - PT) represents one of the few tangible hopes for a left struggling to define itself in a world which currently denies the validity of any socialist aspiration.

Fortunately, there are three recently published works which give the Brazilian Workers' Party the attention that it should have received in North American commentary at least a decade ago. Each work differs widely from the others in its approach and analytic focus. And for this very reason, all three books make an invaluable contribution to the debate and discussion concerning one of the world's most remarkable political movements.

The authors of Without Fear of Being Happy (the title is an exact translation of the PT's slogan during Luiz Inácio Lula da Silva's presidential election campaign of 1989 - "Sem Medo De Ser Feliz") are eminently qualified to write a history of the Workers' Party. Brazilian sociologist Emir Sader 
teaches at the University of São Paulo and has published extensively on both the PT and the Latin American left. American journalist Ken Silverstein was a correspondent for the Associated Press in Rio de Janeiro for three years, having witnessed and chronicled the Brazilian presidential race of 1989. Although Without Fear of Being Happy is largely a journalistic narrative of the PT's birth and development, it also ventures some general observations about the party's unique contribution to the future of left politics. But as Silverstein admitted to this reviewer, the book is not an exhaustive dissertation (e.g. by comparison to Keck's publication). Rather, it is intended to serve as an introduction of the Workers' Party to a readership largely unfamiliar with contemporary Brazilian politics. In this respect, Without Fear of Being Happy is a major success, notwithstanding a few critical flaws in its analysis.

Margaret Keck, Assistant Professor of Political Science at Yale University, has arguably written the most comprehensive review of the PT to appear anywhere (including Brazil). The Workers' Party and Democratization in Brazil is an academic magnum opus, and should be required reading for all university courses dealing with Latin American politics. Keck's initial research began over ten years ago as she was preparing her doctoral thesis at Columbia University. From 1983 to 1991, she made several visits to Brazil, obtaining more interview data as well as witnessing some of the most critical events in the party's evolution. Because she was able to win the well-founded trust of PT activists and leaders, Keck provides the reader with critical insights into the history, structure, personalities, ideological tendencies and internal conflicts of the party.

Although Utopia Unarmed is a contemporary history and analysis of the entire Latin American left, Jorge Castañeda devotes considerable attention to the PT. His comments are based on an impressive review of the secondary literature as well as original interviews conducted with party leaders and Brazilian academics. His work is enjoying enormous commercial success, and has received widespread critical acclaim. Castañeda is a professor of economics and international affairs at the National Autonomous University of Mexico. He also serves as a special adviser on international affairs to Cuauhtémoc Cárdenas, the renowned leader of Mexico's Democratic Revolutionary Party (PRD - Partido Revolucionário Democrático).

Each of the three books offers a very different description of the PT's ideology and praxis. At one end of the spectrum are Sader and Silverstein, who contend that, even though the party has made a radical commitment to democracy, its internal structure creates "a mix between total grassroots control and the Leninist conception of the vanguard." (50, emphasis added) 
They see the PT "as a revolutionary party operating within a bourgeois institutional framework with the express project of installing a new political system, socialism." (99-100) For them, it is nothing short of remarkable that "a radical socialist party" can flourish in a world whose new secular religion has become neo-liberalism.

Castañeda represents the opposite extreme in the debate, contending that the entire Latin American left, including the PT, must come to terms with the "end of history." For Castañeda, the socialist paradigm is fatally discredited, and the left is forced to accept the predominance of the free market. Nevertheless, Castañeda contends that the Workers' Party has much to offer by advancing a program of "social democratic reforms." Castañeda is absolutely explicit in his depiction of the PT as being reformist:

Every now and then, the Brazilian Workers' Party claims that it does not wish to become a reformist, social democratic organization. But if one looks at what it does and not so much at what it says, it is in fact becoming just that. The difference between social democratic reformism and revolutionary socialism consists above all in renouncing the idea of revolution and socialism as a distinct stage of world history, and accepting that the socalled minimum program, or the sum of tactical objectives, and the maximum program, or the sum of strategic aims, become indistinguishable. (153)

As a political scientist concerned with the PT's historical-institutional development, Margaret Keck avoids ideological typecasting. Nevertheless, she leaves the reader with the clear impression of a radically democratic party with utopian aspirations toward socialism, simultaneously rejecting revolutionary Leninist vanguardism and social democratic reformism. In my judgment, Keck's portrayal of the Brazilian Workers' Party is the most authentic.

All three books comment on the following phases of the party's evolution: the founding of the PT in 1980, its 1982 electoral debacle, the party's electoral recovery of the mid and late eighties, and the 1989 presidential campaign. In reviewing these stages of the party's development, Keck, Castañeda and Sader and Silverstein touch on three critical themes: the PT's relationship with the Brazilian labor movement, the integrity of the PT as a class-based party versus the electoral necessity for wider appeal, and the issue of whether the PT should devote its energy and resources to the long-run mobilization and radicalization of civil society versus the pursuit of electoral victories in the existing power structure. 


\section{Formation of the Party}

The major initiative to form the PT came from the "Novo Sindicalismo," or "New Unionism" movement of the late 1970s. At that time, a new generation of labor activists, including Lula, who was then President of the São Bernardo Metalworkers Union, decided to directly challenge the labour court system of compulsory interest arbitration by striking and bargaining directly with the major transnational auto companies. This initiative not only threatened the official labour relations order, but challenged the entire military regime. Brazil's new unionists also perceived the necessity of creating an authentic labour party, since the officially recognized opposition, the MDB (Movimento Democrático Brasileiro - Brazilian Democratic Movement) and its elite leadership, did not effectively represent labour's interests. Consequently, progressive trade unionists launched the PT on 14 October 1979.

Although the new unionists assumed the leading role in the PT's creation, progressive clergy, intellectuals, and activists from other left parties were also involved. Lula maintained that a labour party had to extend its appeal beyond union membership to unorganized wage earners and to the poor in general. He argued against an official institutional relationship between unions and the PT, as such an official nexus would compromise ofganized labour's autonomy.

As central as the industrial working class has been to the PT's development, Margaret Keck surmises that the party will not follow the European pattern of labour politics of the late nineteenth and early twentieth centuries. Several eritical factors contributing to the recent decline of European social democratic parties already exist in Brazil:

The formation of a mass party at this juncture in world history also brings to mind various factors that have been analyzed to explain the decline of mass parties in the European context. The centrality of state bureaucracies in decision making undermines the role of parties in providing access to government; the growing role of the mass media as a source of political information undermines its educational and informational role; the welfare state has replaced the social worker role that some parties once played; an increase in leisure time and a wealth of voluntary associations compete with the party as a social network and as a focus of membership participation; and in some cases state financing has replaced membership financing in importance to these parties. At the very least, the first two of these factors are as salient in Brazil as in the countries for which the decline of the mass party is posited, and the first one perhaps even more so. (14) 
In addition, the PT has to deal with a whole set of social questions going beyond the European tradition. Much of Brazilian organized labour has become increasingly white collar, with the CUT's (Central Única dos Trabalhadores - Sole Central of Workers, Brazil's largest and most dynamic labour central) growth occurring among bankworkers, professionals, and public sector employees. Moreover, environmentalists, feminists, AfroBrazilians, indigenous nations, and gay activists have all gravitated to the PT, further altering a traditionally workerist agenda. In sum, the PT was formed in what Keck calls a politically distinct "time and space," challenging traditional left notions of electoral participation and social mobilization.

Given this distinct and difficult conjuncture for the Brazilian left (and for the left in general), how do each of the writers precisely define the relationship between the PT and the Brazilian labor movement? For Sader and Silverstein, the PT and the CUT are the same thing. (The CUT represents approximately 20 million Brazilian workers from over 1800 affiliated sindicatos (local unions); the CUT has developed parallel, autonomous structures which challenge the official labour relations order, and is the direct outgrowth of the novo sindicalismo movement). Sader and Silverstein imply that the PT went out on strike against itself when São Paulo municipal employees walked off their jobs during the PT administration of Mayor Luiza Erundina:

\begin{abstract}
After taking office, Erundina rapidly adopted a more moderate approach toward municipal administration. Her policies were based on the idea of a 'public sphere,' which she, as the popularly elected mayor, should defend. This orientation was soon tested when strikes by public employees broke out, led by the CUT (and hence the PT). (108)
\end{abstract}

The above depiction is overly simplistic. Although the vast majority of the CUT's base is PT affiliated, there is a minority which is not. A number of CUT leaders and militants are members of the PPS (Partido Popular Socialista - Socialist Popular Party, formerly the Brazilian Communist Party), the PCdoB (Partido Comunista do Brasil - Communist Party of Brazil), the PSB (Partido Socialista Brasileiro - Brazilian Socialist Party), the PSTU (Partido Socialista dos Trabalhadores Unificado - Unified Socialist Party of the Workers, formerly the Convergência Socialista), the PDT of Leonel Brizola (Partido Democrático Trabalhista - Democratic Labor Party), and the PSDB (Partido Social Democrático Brasileiro - Brazilian Social Democratic Party). In no way did the party "create" the labour central in 1983 nor, as Lula insisted from the beginning, was there a formal institutional link between trade unions and the PT, as there had been between the TUC and the British Labour Party, for example. 
Jorge Castañeda assumes precisely the opposite stand. For him, the PT failed to achieve its original goal of becoming "the party of the Brazilian working class." (153) He argues that a fair number of labour leaders have been openly antagonistic to the PT. But Castañeda is most mistaken in assuming that the Workers' Party intended to "hegemonize" the official union structure. Such an idea offended the party's commitment to political and trade union pluralism. Moreover, the PT never attempted to win over the reactionary and pro-corporatist leadership (i.e. the official national confederations). The party always assumed that such elements would be hostile to the PT's support for novo sindicalismo. However, the PT enjoys the active participation and affiliation of many progressive and anti-corporatist trade union militants.

Keck most accurately describes the complex relationship between labour and the party. She notes the significant intersection of leadership between the CUT and PT, and observes that many of the same people have to "act on two different institutional fronts." (184) But Keck insists that the party has never used the unions as instruments of its own policy. She describes the PT as being organically linked with the CUT, but without assuming any vanguard role:

\footnotetext{
The party was not so much to lead workers as to express in the political arena the demands of social movements and unions. The creation of the party was thus a strategic response by a sector of the labor movement for the achievement of goals that had already been articulated elsewhere. It was to be both more than (with regard to what it might achieve) and less than (with regard to its initiative in posing goals and needs) the unions themselves. $(180-1)$
}

\section{The 1982 Elections}

Since its founding, the PT has never questioned the necessity of following the electoral road. Such a conviction is what makes it a political party as opposed to a social or revolutionary movement. Nevertheless, it has struggled to accommodate two goals: using elections as a means of consolidating political organization and strengthening the political expression of social movements in civil society, versus the objective of actually achieving electoral victory in the existing power structure. This internal conflict explains much of the PT's electoral history and performance over the last fourteen years. As Keck has observed, the tension has not disappeared. 
The 1982 Congressional, gubernatorial, and municipal races presented the PT with its first major electoral test. The disappointing results suggested that the party may have been victimized by its internal contradiction over the purpose of electoral politics. The PT won less than five percent of the national vote, electing only eight federal deputies, six of whom were from São Paulo, one from Rio de Janeiro and one from Minas Gerais. It managed to elect one state deputy in Rio de Janeiro, one in Minas Gerais, one in Acre, and nine in São Paulo. The PT won only two mayoral races, Diadema (São Paulo) and Santa Quitéria (Maranhão).

Sader and Silverstein present a descriptive rather than a deeply analytical account of the PT's 1982 debacle. But they leave the reader with the distinct impression that the party had no one to blame but itself and was guilty of having committed fatal tactical errors. They point out that the PT's charter defined electoral participation "as a tool in the organization and mobilization of workers and the construction of popular power" as opposed to actually winning seats. They contend that once the party assigned greater priority to the mobilization of civil society, it opted against

\begin{abstract}
participating in any coalitions even before the restrictive legislation of the military regime was decreed. If the decision made possible the PT's presence as an autonomous force, it ultimately encouraged 'tactical voting' to the great detriment of the party's candidates - opposition supporters casting their ballots for the party with the best chance of beating the military's candidates. (79-80)
\end{abstract}

The PT definitely tried to distance and distinguish itself from the rest of the political opposition. It argued that the PMDB (Partido do Movimento Democrático Brasileiro - Party of the Brazilian Democratic Movement), the successor to the MDB, was elitist, bourgeois and incapable of representing workers' interests. Given its historical longevity and institutional strength, the PMDB had the best chance of defeating the military's party, the PDS (Partido Democrático Social - Democratic Social Party). Consequently, many within the opposition regarded the PT's electoral tactics to be nothing short of divisive, playing into the hands of the military dictatorship. The PMDB exploited these sentiments, and argued that the general public should cast a "useful vote," not wasting its time with a minority party with no political future.

Like Sader and Silverstein, Keck acknowledges tactical errors in the 1982 campaign: placing the party's strongest candidates in the Congressional rather than the gubernatorial races (with the exception of Lula, who unsuccessfully ran for governor of São Paulo), raising middle-class fears by emphasizing the revolutionary past of PT candidates in the free media spots, and 
failing to run sufficiently large party lists in many local races. Nevertheless, she raises the question that Sader and Silverstein miss entirely - what if the party had not attacked the rest of the opposition?

Had the party refrained from attacking the PMDB, proving itself a "responsible" ally within a broader opposition, the impact of the voto util campaign might have been even stronger than it was, particularly among working class voters. Failure to respond would have implied acceptance of the idea that the Workers' Party was indeed a 'party of the future', whose role in the present was to wait. (148)

Keck also points to four powerful incentives motivating the PT's strategy. First, one of the party's founding principles was to differentiate working class political organization from the general opposition. Second, the Brazilian electoral law said that for a party to remain legal, it had to run on its own and obtain five percent of the national vote and at least three percent of the vote in each of nine states. Obviously, the PT had to promote itself in contrast to other parties. Third, the PMDB's attacks against the PT, and particularly those which questioned the intellectual and organizational capabilities of workers, provoked a strongly psychological reaction from party activists. And finally, the positive public response to PT rallies genuinely convinced many party leaders that they stood a fair chance against the PMDB.

\section{The Electoral Recovery}

Immediately after the 1982 setback, many PT activists were inclined to devote their energies to the further mobilization of civil society. For example, union militants in the party helped inaugurate the CUT in late 1983. Nevertheless, the PT realized that it would have to face the next electoral challenge - the mayoral races of 1985 . And to the great surprise and chagrin of the PMDB and other well-established political machines, the PT managed a respectable showing. The party ran candidates in all but one of the state capitals, winning over five percent of the vote in twelve of the races (and over three percent in two others). PT candidate Maria Luiza Fontanelle emerged victorious in Fortaleza, the capital of Ceara and the fifth largest city in Brazil. The PT also placed a close second in Goiânia (Goiás), Vitória (Espírito Santo), and Aracajú (Sergipe), with PT mayoral candidate Eduardo Suplicy garnering twenty percent of the total vote in the city of São Paulo. Despite the initial popularity of the PMDB's anti-inflation program, known as the Plano 
Cruzado, the PT's representation in the Federal Chamber of Deputies jumped to sixteen seats after the 1986 congressional elections. Lula won more votes than any other candidate for federal deputy in the entire history of the Brazilian Congress.

Keck offers us convincing reasons as to why the PT became a serious electoral contender. In the first place, the party was running many more middle-class candidates in the mid-1980s. Such a move appealed to Brazil's sizable professional sector. Keck astutely observes that as the CUT expanded its white collar base, the PT's rhetoric and candidates also changed, given the organic links between the party and the labour central. Moreover, the PMDB could no longer benefit from being the institutional vanguard of the opposition. To the contrary, it had become the ruling party in both the Congress and the Executive, and had aligned itself with direct descendants of the military regime. More and more, the general Brazilian electorate perceived the PT as being the true party of the opposition. Although the two conflicts referred to earlier (working class politics versus wider electoral appeal; mobilization of civil society versus electoral victories) did not disappear in the mid to late eighties, Keck asserts that "the context in which they were discussed did." (156) Given the growing public dissatisfaction with the PMDB's broken promises and its alliances with corrupt and reactionary elements, the whole electoral process "seemed more worthwhile" to PT militants. (156)

All of the elements militating in favor of the PT's electoral viability in 1985 and 1986 also affected the results of the 1988 municipal elections. The PT prevailed in 36 mayoral races, including São Paulo and Porto Alegre. Sader and Silverstein perceptively note that the party was able to capitalize on two realities which had fueled a massive public ire against the PMDB: the monumental failure of the Plano Cruzado to curb inflation and the government's bloody repression of the strike at the National Steel Company in Volta Redonda.

\section{The 1989 Presidential Campaign}

Brazil's presidential race of 1989 was the PT's electoral highpoint. Latin America's superpower came very close to having a decidedly left government in power, with an autoworker and trade union militant as the chief executive. Lula captured over 31 million to Fernando Collor's 35 million votes. During the week prior to the 15 December runoff, the polls indicated that Lula and Collor were virtually in a dead heat. Keck observes, rather cryptically, that the last televised debate only a few days before the election, "followed upon an 
intense burst of negative campaign advertising by the Collor campaign." Keck tells us that "Collor's victory in the second debate probably helped to consolidate his lead" on the eve of the election. (159)

Her lack of commentary concerning the 1989 campaign is in markedly sharp contrast to her detailed and perceptive analysis of 1982 and the mid1980s. She offers us no sense of how the PT brokered its two internal conflicts (class integrity versus public appeal and immediate victory versus mobilization of civil society) at this most critical moment.

The strength of the Sader and Silverstein narrative comes through in their detailed account of the presidential race. Without Fear of Being Happy is unquestionably the best chronicle of the 1989 campaign to have been published in North America. Sader and Silverstein recount those elements contributing to Lula's success in reaching the presidential runoff: the lack of any credible and viable right-wing competition to Collor's candidacy, the PT's skilful use of the free media time, and the PT's unparalleled ability for mass organization, by far the party's strongest electoral asset. Sader and Silverstein also relate in graphic detail all of the destructive methods employed by the Collor campaign in the second round, which Keck euphemistically terms "intense negative campaigning." TV Globo's biased editing of the final televised debate, the Collor campaign's bribery of Lula's ex-companheira Miriam Cordeiro to engage in slander, the media's libelous attempt to link the kidnapping of Brazilian businessman Abilio Diniz with the PT, and the interruption of public transportation on election day by anti-Lula local bosses in the North and Northeast, are all tactics which Sader and Silverstein report with shocking clarity.

\section{Conclusion}

As I suggested at the beginning of this review, each of the three books presents a distinctively different version of the PT's ideology and praxis. As noted earlier, Sader and Silverstein depict the PT as a "revolutionary party in a bourgeois institutional framework," still partially attached to the "Leninist conception of the vanguard." Both Keck and Castañeda reject such a characterization, and I would join them in their assessment. The depiction misleads the reader into thinking that the PT has breathed new life into Leninist orthodoxy, when, in fact, the very opposite is the case. The PT made a conscious and definitive break with what it perceived as the anti-democratic practices of the revolutionary left, making internal democratic process a fundamental priority.

Being the thoroughly open, ecumenical, non-doctrinaire, mass-based, and democratic party that it is, the PT has accepted tendencies which claim to 
be revolutionary and pledge allegiance to democratic centralism. But as much as these minority tendencies (i.e. the PCBR - Brazilian Revolutionary Communist Party and the Convergência Socialista) advocated Leninist tactics, they failed to achieve ideological or organizational hegemony. To the contrary, a majority bloc known at the Articulação, consisting of trade unionists, Catholic activists and intellectuals, thoroughly rejects vanguardism and advocates the principles of internal democracy.

It is undeniable that the party expects each member to abide by its decisions once they have been democratically determined. (For example, federal deputies Airton Soares and Bete Mendes were forced to leave the PT when they refused to obey the party's decision to boycott the electoral college selection of Brazil's president in 1984.) But such a policy of internal discipline is altogether distinct from the practice of revolutionary cadres imposing their "wisdom" on the majority.

The PT made its policy of internal democratic governance most explicit in its national directorate's resolution of 1986 :

1. The PT is a democratic, socialist, and mass-party. It is therefore not a front of political organizations, nor is it an institutional mass-front that can be used as an instrument by any political party.

2. As a democratic party, the PT defines and exercises the recognition of the will of the majority, assuring at the same time, the existence of minorities and their right to be represented and to express themselves in all instances of the party.

3. The national meeting recognizes the right of the tendência and determines that the next national diretorio will proceed with their regulation. But the party understands that this right cannot be extended to groups which do not adopt the program of the PT nor to those which do not accept its democracy and discipline. In the same vein, the right of the tendência does not authorize militancy in parties other than the PT. (Keck, 117-18)

Since the Trotskyist tendency known as the Convergência Socialista had chronically violated the first and third principles of the party's 1986 resolution by using the PT as a front for its own purposes, it was expelled two years ago.

Perhaps the clearest rejection of revolutionary vanguardism came from the mouth of Lula himself:

[The PT] is a party born out of the consciousness that workers won after many decades of serving as a mass to be manipulated by bourgeois politicians and of listening to the ballads of the supposed vanguard parties of the working class. Only the workers can win what they have a right to. No one ever has and no one ever will give us anything for free. (Quoted in Keck, 126) 
Jorge Castañeda's characterization of the PT as being nothing more than social democratic and reformist must also be submitted to intense scrutiny and criticism. Castañeda makes the sweeping assertion that all of the Latin American left committed to the electoral path fits the reformist mold. He argues that the Latin America left accepts the moderate social democratic reform of market capitalism because the "revolutionary socialist paradigm" has collapsed entirely. He associates the revolutionary model with both Castro's Cuba and the command economies of the former Eastern bloc. Although he admits the existence of a "discontinuity between the Cuban revolution and the theory and practice of traditional Communist parties of Latin America," Castañeda contends that the economic planning of "the Soviet Union and Eastern Europe did form the model the Cubans and their followers believed in." And "one party rule, expropriation of the means of production, and aspirations of social homogeneity did represent undisputed features of the model in question." (73)

Castañeda contends that the death of the revolutionary socialist paradigm leaves the Latin American left "without a future ... For now, this vision of a better state of things to come is no longer credible and, consequently, no longer functional." (242) The most that the Latin American left can realistically aspire to is "nothing more - though nothing less - than an adjusted, middle-of-the-road economic policy." (248) A kind of socially responsible minimalism is all that can be expected:

By formally and sincerely accepting the logic of the market, and then immediately and equally sincerely endorsing the variations, regulations, exceptions, and adaptations the European and Japanese market economies have adopted over the years, the Latin American left can set the stage for the construction of a paradigm that is substantially different from the present state of affairs. (432)

Castañeda admits that the PT professes to be a democratic socialist party, but he asserts that "in everyday political life it has clearly deprived the term "socialism" of much of its content." He believes that the Brazilian Workers' Party, like the rest of the left worldwide, is going through a kind of maturation process, and will eventually "grow out of" the infantile fixation with the socialist ideal. (154)

Quoting Brazilian sociologist Fernando Henrique Cardoso as if he were an objective academic source (Cardoso is the PSDB candidate who recently prevailed in the 1994 presidential elections and actively opposed Lula's candidacy with a highly neo-liberal/pro-privatization agenda), Castañeda tells us that "in Brazil, social democracy is divided into three: the Brazilian Social Democratic Party (PSDB), Leonel Brizola's Partido Democrático Trabalhista 
(PDT), and Luiz Inácio da Silva's ("Lula's") Partido dos Trabalhadores (PT)." (143) Thus, for Castañeda, the three parties are essentially the same, and they "complement each other" with their respective assets. (144)

The collapse of what Castañeda calls the revolutionary socialist paradigm never left the Brazilian Workers' Party "lost" and "without a future." The PT never identified with the Soviet and Eastern bloc to begin with, and it completely rejected the notion of a centralized command economy with an anti-pluralist political order. Castañeda concedes that the PT's concept of socialism is a far cry from the Cuban model, and he quotes Lula saying the following in a 1991 interview in Mexico City:

The PT criticized Eastern Europe from its birth. We criticized the Berlin Wall, state bureaucracy, the absence of union freedom; we defended

Walesa from the moment we were founded. (342, footnote 21$)$

The problem with Castañeda's concept of socialism is that it is entirely economistic, static, and non-dialectical. This may be due to his particular training as an economist, but it makes for defective social and political analysis. In fact, Castañeda appears to have ignored the social and political dimension altogether. His conclusions assume a false discontinuity between economic program and genuine efforts to democratize the state and civil institutions. For him, if the left rejects the centralized economic model, it must reject socialism altogether.

The notion of socialism as the dynamic effort toward maximizing democracy, without a fixed economic masterplan, and guided by such principles and policies as majority rule, protection and proportional representation of minorities, public control of strategic industries (such as petroleum and telecommunications), granting genuine participation to workers and communities in managerial and investment decisions of strategic enterprises, localizing and decentralizing state authority, and encouraging the growth of voluntary collective organization in civil society, is not really contemplated by Castañeda's limited and dualistic construct. Yet, the Brazilian Workers' Party advocates all of the policies noted above, as evinced in its charter, convention resolutions, internal rules, its platform for the 1994 elections, and its recent history of state administration, particularly at the municipal level. To label these as mere "social democratic reformism" is to deny the unprecedented potential of radical democratic initiative.

Castañeda's depiction of the PSDB, the PDT, and the Workers' Party as having "different assets," but sharing essentially the same ideology and philosophy of political action, thoroughly depreciates the PT's salient uniqueness. The PT is far more than a progressive party having "an organization, a working class constituency, and a rural following." Thoroughly unlike the 
PSDB and the PDT, the Workers' Party is a genuinely mass-based political organization which is determined entirely from the bottom up, thoroughly eschews traditionally elite or caudilho-directed populism, and has the most radical and demanding system of internal democracy in the history of Brazilian politics.

Margaret Keck's final chapter most faithfully depicts the PT's nature and character. Successfully capturing the highly voluntarist and anti-statist disposition of the party, she describes the PT as having a "conception of politics" as "a process of claiming rights in practice, rather than demanding their concession by the state." The party believes that "through the self-organization of society, the relations of power between state and society would change, and a new agenda based on societal needs would be created." (245) The idea of the good society is not overly "theorized in PT discourse, because it will emerge from the democratic practice of autonomous social actors." (245, emphasis added) The party's concept of socialism is not really an ideology (and far less a program), but an "ethical proposal, within which a number of alternative visions of the good society competed, using different languages." (245) Keck rejects the suggestion of Sader and Silverstein of a persisting vanguardism, but also discards Castañeda's theory of "social democratic reformism." (247) Keck captures the social and political dimension of the socialist inspiration which Castañeda misses entirely. She suggests that the PT represents a socialist alternative which Castañeda's typology fails to embrace. She argues that the party "has an intuition, if not a theoretically elaborated argument, that the socialism to which it aspires is also, and essentially, an aspiration for democracy." (250)

Since the presidential race of 1989 , the Brazilian Workers' Party has successfully managed to pursue its goal of strengthening civil society, while, at the same time, maintaining its electoral viability. With the approval of the PT, Lula declined to seek another term as federal deputy in 1990, opting to serve as president of the party instead. Over the last two years, he galvanized grassroots support by personally visiting every region of the country by bus, train, and boat. His efforts, along with those of numerous other party activists, produced significant electoral gains. In the 1992 municipal elections, the PT swept fifty six cities, including the state capitals of Porto Alegre, Rio Branco, Goiânia, and Belo Horizonte.

The impeachment of President Collor in late 1992 for his involvement in an elaborate kickback scheme and subsequent revelations of corruption on the part of center-right federal deputies only enhanced the PT's credibility and respect among the general electorate. From late 1993 until July of 1994, Lula led all the polls for the 1994 presidential election, having reached an impressive 40 percent during his visit to the United States in May. At that time, he led his closest rival, Fernando Henrique Cardoso of the PSDB, by over a two to one margin. 
Cardoso resigned as economics minister in the Itamar Franco government in order to compete in the 1994 presidential campaign. About two months prior to his exit from the administration, Cardoso's technical advisers designed another program to curb Brazil's incorrigible inflationary spiral the Plano Real. The plan created a new currency roughly equivalent in value to the U.S. dollar. Cardoso has been regarded as one of Brazil's most prominent left intellectuals. His works on modern sociology have been read the world over. When he ran for federal senator (São Paulo) on the MDB ticket in 1978, he was actively supported by many of Brazil's new unionists, including Lula. As he and other progressive politicians in the PMDB became increasingly disaffected with their party's rightward shift, they decided to launch the PSDB in the mid-eighties.

But in order to maximize his chances for the presidency in 1994, Cardoso abandoned his left and social democratic past. He closed ranks with one of Brazil's most right-wing parties, the PFL (Partido da Frente Liberal Liberal Front Party), and advocated a radically neo-liberal platform of virtually unconditional free trade and economic integration with the rest of the hemisphere and unrestricted privatization of all state enterprises, including the strategic sectors of petroleum and telecommunications. Inflation continued unbridled even after the inauguration of the Plano Real, as high as fifty percent for the month of June. But with the concerted efforts of the Central Bank and Brazil's merchants to avoid a PT victory in October, inflation plummeted to 6 percent in August and 1.5 percent in September. Cardoso predictably reaped the benefits. In the week prior to the 3 October elections, the polls showed Cardoso climbing to 46 percent with Lula trailing at 24 percent.

The government played its hand with regard to the master strategy. About three weeks before the election, Economics Minister Rubens Ricupero publicly admitted that the purpose of the Plano Real was to get Cardoso elected, and that he (Ricupero) had no scruples regarding achievement of the ultimate objective. Despite such a cynical admission from the government, general skepticism about the plan's longevity, and Lula's arguments that the Plano Real failed to confront the structural causes of inflation, such as the external debt, financial speculation, and oligopolistic pricing, the Brazilian public decided to believe that Cardoso was truly a magician. He won approximately 34 million votes to Lula's 17 million, with the rest of the candidates following far behind. Cardoso captured fifty four percent of the validly-cast votes, obtaining a majority in the first round.

The question of how the PT could have lost its overwhelming lead in such a short period of time has been the source of grueling soul-searching and self-criticism over the past several days. Some have faulted Lula for making such a "frontal" attack on a popular plan. Others blame the party for not having mobilized its public rallies and the get-out-the-vote campaign much 
earlier. It is still too early to assess all the factors contributing to Cardoso's victory. Massive financial backing from Brazil's wealthy elites, editorial favoritism and endorsements from Brazil's media monopolies (e.g. the Globo empire) and direct assistance from James Carville, Bill Clinton's renowned campaign manager, certainly helped, to say the least. Given the fabricated timing of the Plano Real's "success," it is not clear that Lula or the PT could have really done anything to avert the situation.

But even with its presidential hopes dashed for now, the PT has proven that it is still a formidable contender. Lula's showing was respectable and well ahead that of third-place challenger Eneás Carneiro of the ultra-nationalist and fascist-inspired Partido da Reedificação da Ordem Nacional (Party of the Reconstruction of the National Order), who weighed in with 4.6 million votes. Moreover, the Workers' Party is expected to increase its representation from 37 to 70 seats in the Federal Chamber of Deputies (the votes are still being counted) and has gone from 1 seat to 5 in the Senate. The party also gathered enough votes to qualify for the 15 November gubernatorial runoffs in Brasília, Espírito Santo and Rio Grande do Sul. It has consolidated enough political space in the last election to do that which it has done best over the last fourteen years: offer the Brazilian people a credible, principled and effective opposition. Without question, the PT continues to be a very serious party. And for the left throughout the world, Brazil will continue to be a very serious country. 